УДК 343.98

DOI https://doi.org/10.32837/pyuv.v0i4.633

\author{
Л. В. Гусар \\ orcid.org/0000-0002-0768-8050 \\ кандидат юридичних наук, \\ доцент кафедри кримінального права \\ Чернівецького національного університету імені Юрія Федьковича
}

\title{
ПОБУДОВА ПОШУКОВОГО ПОРТРЕТА СЕРІЙНОГО ЗЛОЧИНЦЯ
}

Постановка проблеми. Пошуковий портрет злочинців складається зазвичай під час розслідування серійних насильницьких злочинів - згвалтувань, сексуальних вбивств, ритуальних вбивств. Криміналістична практика розробки і реалізації пошукових портретів серійних злочинців має багаторічну історію. Проте протягом багатьох років всі розшукові слідчі дії та виявлення й викривання злочинців базувались на практичному досвіді й «оперативному відчутті» тих, хто здійснював розслідування.

Аналіз останніх досліджень i публікацій. Грунтовних наукових дослідження розслідування серійних злочинів не проводилось. Взагалі в СРСР фундаментальні психологічні і криміналістичні теорії щодо розслідування серійних вбивств і розкриття інших резонансних насильницьких злочинів почали з'являтися на початку 90 -х років, після того як було доведено, що більше десятка вбивств на трасі між Вітебськом і Полоцьком вчинила одна людина... [1, с. 122]. В Україні відмічається позитивна динаміка публікацій у наукових виданнях правознавців, кримінологів, психологів, криміналістів, які присвячені тим чи іншим аспектам боротьби із серійною насильницькою злочинністю, в тому числі і розробці пошукових портретів. Так, в Бюлетені з обміну досвідом роботи МВС України № 131 було опубліковано статтю А.В. Стурушкевича «Криміналістичне профілювання як метод криміналістичного аналізу», в якій розглядається технологія створення пошукового портрету злочинця і наводяться конкретні рекомендації щодо реалізації розроблених пошукових портретів злочинця [2, с. 56].

Виклад основного матеріалу. В кожному конкретному випадку пошуковий портрет злочинця є результатом комплексного міждисциплінарного аналізу матеріалів кримінального провадження.

Процедуру складання портрету злочинця можна запозичити із західної моделі кримінального профайлінга («профілінг» від слова «профіль» портрет). Інформація про особу, яка вчинила злочин, отримується 3 аналізу даних огляду місця події, допиту свідків, матеріалів, які містяться в висновках експертизи, проте ми одержуємо інформацію про особистість злочинця, а не точне прізвище й повну адресу. Ця інформація дозво- лить створити ймовірну модель злочинця з характерними рисами його внутрішнього (психічного) i зовнішнього (конституційного) вигляду, а також професійною орієнтацією, стилем життя, захопленнями. «Збіг підозрюваного з моделлю допоможе викрити злочинця, а розбіжність - відвести підозру від невинного. А до того як з'явиться конкретний підозрюваний, можливе створення його психологічної моделі, образа» [3, с. 36].

У складанні пошукових портретів злочинців беруть участь науковці, практичні працівники різних галузей - експерти-криміналісти, кримінологи, психологи і психіатри. Аналізуючи матеріали справи, вони, за результатом їх спільної діяльності, складають висновок (довідку), який має рекомендаційний характер.

Залежно від змісту й характеру отриманої інформації пошуковий портрет невідомого злочинця містить такі дані: загальна характеристика особистості і формуюча мотивація поведінки; звички, схильності, навички та інші індивідуальні ознаки особистості; вікова група; район, де ймовірно проживає злочинець; район місця роботи, служби, навчання; рівень освіти й професійна діяльність; особливості родини та історія особистого життя; сімейний стан і наявність дітей; служба в армії, заняття спортом, робота з людьми; наявність судимості (кримінальна обізнаність); наявність психічної патології; антропологічна i функціональна характеристика (тип зовнішності, пантоміміка тощо).

Криміналіст А.А. Протасевич запропонував свою типову модель пошукового портрета злочинця, яка складається з трьох блоків [4]. Перший ознаки, що характеризують злочинця як об'єкт реального світу і як особистість (демографічні, соціально-демографічні, функціональні, психічні). Другий - ознаки типу «зв'язки - відносини» (ставлення злочинця до потерпілого, до викраденого майна, до місцевості, на якій розташоване місце події). Третій - ознаки злочинця як суб'єкта кримінальної активності та об'єкта, що приймає участь у процесі слідоутворення (дії злочинця до, під час і після вчинення злочину; сліди на тілі, одязі злочинця й на об'єктах, що взаємодіяли з ним).

Наявні також і більш детальні наукові розробки цього методу під час розслідування серій- 
них насильницьких злочинів. Так, фахівцям для складання пошукових портретів серійних вбивць рекомендується звертати увагу на фактор часу нападу злочинця на жертву. При цьому доцільно зафіксувати день тижня і його особливості (робочий, вихідний, свято). Крім того, необхідно вказати можливий зв'язок часу вчинення злочину 3 робочим режимом цього пункту місцевості: закінчення роботи середньої школи, підприємства; збільшення кількості людей в місці вчинення злочинів чи, навпаки, зниження їхньої кількості.

Рекомендується також ураховувати:

1. Особливості погодних умов у момент вчинення злочину. Треба встановити: чи йшов дощ, яким був атмосферний тиск, у якій фазі знаходився місяць тощо.

2. Маршрут жертви. Особливу увагу треба звернути на пересування жертви в межах останньої години до моменту нападу, а також маршрут від передбачуваного місця контакту жертви зі злочинцем до місця вчинення злочину або виявлення трупа.

3. Маршрут злочинця. За відсутності таких даних доцільно зробити припущення про можливі шляхи і способи його пересування, відзначивши: а) можливі шляхи прибуття в цей район; б) можливі шляхи відходу; в) місце, з якого злочинець вистежував жертву.

4. Дані про жертву і спосіб контакту злочинця. Почерк злочинця часто виявляється в способі контакту злочинця із жертвою, у зв'язку з чим треба звертати увагу на таке: ступінь оголення жертви; можливі варіанти сексуальних контактів з неоголеною жертвою.

5. Особливості місця події. Під час складання протоколу огляду місця події важливо відзначити: можливість під’їзду транспорту, наявність зупинок транспорту і якого саме, а також з'ясовується, який вид транспорту здебільшого використовується населенням.

Під час розслідування серійних насильницьких злочинів особливо важливого значення набуває прогнозування місця майбутнього злочину. Оперативних працівників правоохоронних органів, що здійснюють розшук і затримання підозрюваних у вчиненні серійних насильницьких злочинів, особливо сексуальної мотивації, найбільше цікавить питання: де і коли можна затримати злочинця під час спроби чергового нападу [5, с. 95]. Зважаючи на те, що прогнозувати місце майбутнього злочину досить важко, слід зазначити, що у свідомості злочинця місце злочину буває обране заздалегідь. Крім того, воно зумовлюється маршрутом жертви. I якщо жертва виявиться там, то злочин, імовірніше за все, буде скоєно. Місць, що задовольняють вимоги злочинця, небагато. Вже після першого злочину можна передбачити наступне місце. Тому важливо і необхідно ви- значити подібні місця на місцевості і взяти їх під спостереження. Як зазначають західні експерти, злочинець обов'язково «обходить» свою територію і часто повертається на місце злочину.

Прогнозувати наступне місце злочину можливо за допомогою таких критеріїв: обмеженість простору (відкритий простір чи приміщення); ймовірність, що жертва перебуватиме на місці злочину одна; присутність злочинця в цьому місці не має викликати підозру; освітлення; час; відстань до житлових будинків; відстань до найближчого пішохідного маршруту або транспортної магістралі [6, с. 385].

Ці умови індивідуальні й специфічні для кожного окремого злочинця і зазвичай залишаються незмінними протягом серії злочинів. Найбільш сталою характеристикою місця злочину є те, відкритий (парки, лісопарки) це чи закритий (ліфти, підвали) простір, що має для злочинця принципове значення і зберігається тривалий час.

В обмежених умовах (місто, селище міського типу) для нападу з метою згвалтування або вбивства на сексуальному грунті найбільше часто злочинці вибирають: ліфти багатоповерхових будинків, горища, підвали, під'їди, сходові площадки, сквери, лісосмуги, будмайданчики [7, с. 6].

У великому населеному пункті можливі три варіанти «злочинної географії»: на всій території міста; на обмеженій території (1 район); декілька місць, які згруповані на суміжній території (2-4 райони). В останньому варіанті для кожного з окремих районів визначаються власні межі, а потім в центрі кожного з виділених районів ставиться "крапка». Вони є основою для побудови схеми території району дії злочинця [1, с. 127].

Після виявлення всього району дій злочинця необхідно конкретизувати та позначити ті місця, де найбільше ймовірна його поява. Відповідно, саме там треба організовувати першочергові оперативно-розшукові заходи по затриманню злочинця. Співставивши маршрути всіх жертв, можливо визначити конкретне місце, в якому злочинець спробує вчинити наступний злочин.

Необхідно враховувати, що місце нападу і вистежування жертви спеціально розраховуються злочинцем так, щоб забезпечити максимальну кількість потенційних жертв. Це можуть бути зупинки транспорту або шлях, яким повертається жертва після роботи чи навчання [8, с. 240].

Поряд із місцем вчинення злочину існує так зване місце початку злочину - місце вистежування жертви («місце старту»). Місць вистежування жертви може бути декілька. Останні, на відміну від місця вчинення злочину, більш стабільні за своїми криміналістичними характеристиками. Щоб визначити місце вистежування жертв, необхідно з'ясувати місце, в якому останній раз бачили потерпілих, і ретельно вивчити їхній маршрут. 
Зіставивши маршрути жертв, можна прогнозувати місце, в якому злочинець може знову спробувати ввійти в контакт із черговою жертвою. Водночас наявні ситуації, коли злочинець працює на відповідній роботі (перукарня, ательє, басейн, лазня) і може безперешкодно вибирати чергову жертву, тобто діє стаціонарно.

Важливе місце під час аналізу серійних насильницьких злочинів набуває фактор часу. Практика показала, що злочинець віддаляється від вихідного пункту (станції метро, зупинки) приблизно на однакову відстань. I якщо спробувати зрозуміти, чому злочинець вчиняє злочини на однаковій відстані від вихідного пункту, то виявляється, що однаковим є не відстань, а час. Тобто злочинець визначає час для прибуття на місце злочину [9].

Здебільшого час вчинення нападу не є чимось випадковим, він містить досить багато інформації для створення пошукового портрету злочинця, особливо якщо профілеру вдасться виявити закономірності його вибору останнім.

Закономірності вибору часу вчинення злочину визначаються за двома напрямами:

а) час доби нападу;

б) частота вчинення нападів (в які дні, місяці).

Ці позиції не пов'язані одна з одною і аналізуються окремо. На вибір часу доби вчинення злочину впливає імовірність появи жертви в місці, що підходить для нападу. На частоту вчинення злочинів впливають характер і рівень нереалізованих потреб злочинця, які своєю чергою залежать від погодних умов, фази місяця, режиму роботи, навчання. Узагальнений досвід показує, що напади з метою згвалтування відбуваються переважно об 11, 14, 19 і 22 годині. Цікавий факт, що після 22 години частота нападів зменшується, хоча серед населення переважає думка, що цей період найбільш небезпечний в цьому аспекті.

Пік росту числа серійних насильницьких злочинів, які зумовлені, насамперед появою на вулиці найбільшої кількості потенційних жертв, припадає на 14-15 годину - час закінчення занять у школах, або на 16-17 годину - закінчення занять в училищах, інститутах, або на 18-19 годину - закінчення роботи, або на 22 годину - повернення $з$ вечірніх гулянок, з гостей. Але для профілера важливо визначити не тільки час вчинення нападу на жертву, а з'ясувати, чим зумовлений вибір саме цього часу для злочинця.

Досліджуючи проблему часового фактору вчинених злочинів, профілер пов'язує з ним заходи щодо захоплення злочинця. При цьому важливо враховувати: вчинення серії насильницьких злочинів в однаковий період доби, наскільки відрізняються криміналістичні характеристики порівнюваних злочинів, зв'язок з початком або закінченням навчання в місцевих навчальних закладах, роботи підприємств і організацій, пере- рвами на обід, часом проведення культурно-масових заходів.

Для створення пошукового портрету злочинця, профілеру важливо звернути увагу на день тижня, в який відбувалися напади, і чим він примітний для цієї місцевості.

Наступним важливим моментом, що характеризує час вчинення злочину, є погодні умови. Останні наукові дослідження фахівців Академії ФБР (США) довели, що на кримінальну активність серійних сексуальних злочинців впливає не стільки сама погода, скільки зміна атмосферного тиску. Для більшості серійних злочинців періодом найбільшої сексуальної активності $€$ весна i осінь. Найменше сексуальних нападів вчиняється узимку [10, с. 155-162].

Ю.М. Антонян, який більше 30 років присвятив вивченню поведінки серійних сексуальних злочинців, в тому числі i розробці пошукових портретів, описує їх «подвиги» у такий спосіб: «Орудуючи найчастіше під прикриттям ночі, сексуальні вбивці, як первісні мисливці, спочатку вистежують свої жертви, раптово нападають на них, наносять безліч тілесних ушкоджень, несамовито розпорюють груди і живіт, вивертають внутрішності, вчиняють наруги над статевими органами, відрізають окремі шматки тіла... Ці злочини вражають своєю неймовірною жорстокістю, безлюдяністю, великою кількістю жертв, серед яких чимало дітей... Створюється враження, що на світло вирвалися міфічні чудовиська, жорстокі Слуги смерті, що не знають почуття жалю... Це враження ще більше підкріплюється, коли виявляються факти поїдання ними окремих частин тіла вбитих...» [11, с. 220].

В Україні цих прикладів скільки завгодно. На жаль, криваві «пригоди» Оноприєнка, Куліка, Поліщука відомі всім... Сумнозвісна справа зоотехніка Г. одна з них: «..його прозвали «удавом». Відрізнявся цей «герой» кривавого серіалу любов'ю до хлопчиків, але дуже дивною любов'ю... Починаючи із середини 80 -х років в лісових масивах почали знаходити трупи хлопчиків у віці від 10 до 15 років зі слідами катування і знущання. Коли злочинця все ж таки піймали, то навіть у досвідчених сищиків волосся на голові ставали дибом... У бетонному підвалі-бункері гаража, куди Г. заманював своїх жертв, була справжня «лабораторія смерті»... При яскравому електричному освітленні він орудував набором ветеринарних інструментів, а також сокирою, лопатою, шприцом, синтетичною мотузкою... Вбивав, підвішував живих і мертвих на гаки, знімав з них скальпи, розрізав тіла на шматки, вирізав фрагменти м'язових тканин, знімав і засалював шкіру тих, хто опинився в його лігвищі. Вся ця страшна картина відкрилася перед очима слідчого й оперативних працівників, що оглядали підвал Г. Не пройшла повз 
уваги й оцинкована ванночка, в яку спускалася кров вбитих. I хоча кров спалювалася за допомогою паяльної лампи, під час її огляду знайшли залишки крові і шматочки препарованої шкіри...» [12].

На думку Ю.М. Антоняна, жорстокість в структурі злочинної поведінки вбивці виступає як засіб його самоствердження. «Муки, катування, знущання, - підкреслює Ю.М. Антонян, - приносять йому неймовірне задоволення, він відчуває всю повноту і велич своєї особистості, підтверджує своє місце в житті... Знищив іншого, злочинець прагне компенсувати всі ті страждання і приниження, які йому довелося пережити раніше...» [13, с. 223-224].

Скільки ж їх, потенційних, ще не пійманих «монстрів» блукають Україною? Точної відповіді на це питання не знає ніхто. Армія сексуальних маніяків швидко росте. Цьому сприяють економічна розруха, корумпована влада і кримінальна злочинність, поширення фонових явищ, зокрема алкоголізму та наркоманії, і насамперед духовна деградація українського суспільства, його моральний занепад.

Як підкреслює психіатр О. Бухановский, людей із психо-сексуальними аномаліями набагато більше, ніж це зафіксовано в статистичних документах. Якщо не будуть прийняти рішучі заходи, то найближчими роками варто очікувати вибуху серійних насильницьких злочинів. I, на жаль, цей сумний прогноз відомого вченого виглядає дуже реалістично, оскільки реалізовується 2-й етап медичної реформи. Не менш жахливим $є$ те, що практика розкриття серійних насильницьких злочинів, які були вчинені сексуальними маніяками, залишає бажати кращого.

На думку Ю.М. Антоняна, під час розробки пошукових портретів злочинців, які вчиняють серійні сексуальні вбивства, варто враховувати те, що за зовнішньою однаковістю серійні сексуальні вбивства істотно відрізняються один від одного. Змпозиції криміналістичної психології можна відокремити такі групи: а) вбивство осіб жіночої статі і підлітків з метою зломити їх опір; б) вбивство з метою схову іншого насильницького злочину (наприклад, вбивство після зґвалтування); в) вбивство, коли злочинець одержує статеве задоволення від муки й агонії своїх жертв (це найбільш небезпечна категорія сексуальних злочинців) [11, с. 165].

Визначити, до якої групи належить злочинець, можна на першій стадії розслідування, що дозволяє побудувати результативний пошуковий портрет серійного сексуального вбивці.

Порівняльний аналіз даних вітчизняних і зарубіжних фахівців, що аналізували поведінку сексуальних маніяків-вбивць, дозволяє зробити висновок про збіг базових характеристик пошу- кового портрету серійного злочинця, що діє як в Україні, так і з їі межами. Насамперед це стосується соціально-психологічних параметрів особистості маніакальних вбивць із сексуальною патологією, а також генези, мотиваційного механізму і закономірностей, що лежать в основі їх протиправної до- і посткримінальної поведінки.

Ця обставина створює передумови для вдосконалення практики боротьби із серійною насильницькою злочинністю на основі міжнародного обміну криміналістичним досвідом, що був накопичений в галузі створення пошукових портретів серійних злочинців. Водночас відкривається можливість для подальшого розвитку наукових досліджень психологів, криміналістів, кримінологів, шляхом взаємообміну ідеями, творчої реалізації емпіричних даних і досягнень закордонних колег.

Як зазначив Е.Г. Самовичев, кримінальна подія в поведінці серійного вбивці реалізується «за механізмом резонансних відносин між хронотипами злочинця і жертви. Вибір жертви є невипадковим. В їі тип модулюються істотні риси типу злочинця, хоча форми зовнішнього прояву можуть бути різними» [14].

В Україні поступово застосовується цей криміналістичний метод в практику розслідування серійних насильницьких злочинів. Як фахівець для складання пошукового портрету злочинця (профілера) залучався експерт-психолог. Щодо цього Державним науково-дослідним експертно-криміналістичним центром МВС України був виданий інформаційний лист №19/1-1200 від 3 квітня 2003 року «Про позитивний досвід залучення експерта-психолога до розслідування злочину, застосований в НДЕКЦ при УМВС України в Миколаївській області». Так, на території м. Миколаєва за період з 8 вересня 2002 року по 23 жовтня 2002 року було скоєно серію з трьох насильницьких злочинів. На вказані злочини у складі слідчооперативної групи виїжджала експерт-психолог О. Болотян, яка залучалась криміналістичним центром як спеціаліст для найбільш ефективного та повного огляду та аналізу місця події, а також з метою складання пошукового портрету злочинця для полальшого цілеспрямованого розслідування [15]. За результатами роботи на місці події, перегляду відео-, та фотоматеріалів, опрацювання протоколів оглядів місць подій, висновків судмедекспертів, спеціалістом-психологом були складені пошукові портрети злочинців. Крім того, за фактом вбивства гр. Т. в результаті слідчо-оперативних дій, в тому числі і завдяки роботі експерта-психолога по складанню пошукового портрету злочинця, було затримано гр. Л. 1967 р. н. за підозрою у вчиненні злочинів.

Висновки. 3 метою підвищення ефективності діяльності правоохоронних органів по розслідуванню серійних насильницьких злочинів, пропо- 
нуємо такі рекомендації: 1) розробити принципово нову методику розслідування серійних насильницьких злочинів шляхом складання пошукових портретів злочинців; 2) створити інформаційну базу даних (інформаційно-пошукову систему) про серійних злочинців з урахуванням базових складників пошукового портрету злочинця (стать, вік, сімейний стан, освіта та інший); 3) мзапровадити нові експертні системи та системи підтримки прийняття рішень для роботи фахівців по складанню пошукових портретів злочинців (профілерів); 4) запровадити обов'язкову реєстрацію серійних злочинців, які мають певні відхилення психічного розвитку; 5) налагодити обмін інформацією про пошукові портрети злочинців зацікавленим відомствам, як в Україні, так і за її межами; 6) організувати відповідні наукові дослідження в галузі створення пошукових портретів злочинців; 7) організувати навчання спеціальних фахівців - психологів-криміналістів, які надаватимуть висновки не тільки щодо розробки пошукових портретів, але й інформацію щодо стратегії затримання і допиту злочинців тощо.

\section{Iimepamypa}

1. Образцов В.А., Богомолова С.Н. Криміналістична психологія. Москва, Юніті, 2002, 444 с.

2. Старушкевич А.В. Криміналістичне профілювання як метод криміналістичного аналізу. Бюлетень МВС України. Київ, 2001. №131. С. 52-57.

3. Втюрін Л.А. Нетрадиційні методи розкриття злочинів. Серійні вбивства і соиіальна агресія. Ростов-на-Дону, Фенікс, 1994. С. 36.

4. Протасевич А.А. Пошуковий портрет злочинця як інтегративна система. I., 1999. 321с.

5. Протасевич А.А., Образцов В.А. Розкриття вбивств. І., 1998. $234 \mathrm{c.}$

6. Keeny B., Heide K. Gender differences in serial killers. JIV, 1994. Vol. 9. P. 383-398.

7. Петухов В.О. Про розробку в Росії психологічних портретів осіб, що вчиняють серійні злочини проти особистості. Записки криміналістів. Москва, Юрикон, 1994, Вип.4. С. 5-13.

8. Дуглас Д., Олшейкер М. ФБР проти серійних вбивць. Москва, Кронн-пресс, 1998. 254 с.

9. Lane B., Gregg W. The new encyclopedia of serial killers. L., 1996. P. 456.

10. Гримак Л.П. Методи прикладної психології в розкритті та розслідуванні злочинів. Москва, 1999. $432 \mathrm{c}$.

11. Антонян Ю.М. Серійні сексуальні вбивства. Москва, 1997. 234 с.

12. Образцов В.А. Серійні вбивства як об'єкт психології і криміналістики. Москва, Омега, 2003. 205 с.

13. Антонян Ю.М. Психологія вбивства. Москва, 1997. $260 \mathrm{c}$.

14. Самовичев Е.Г. Деякі прикладні питання аналізу серійних злочинів. Збір. наук. праць НДІ МВС Росії. Москва, 1993. С. 14-15.

15. Інформаційний лист ДНДЕКЦ МВС України № 19/1-1200 «Про позитивний досвід залучення експерта-психолога до розслідування злочину, застосований в НДЕКЦ при УМВС України в Миколаївській області» від 3 квітня 2003 року.

\section{Анотація}

Гусар Л. В. Побудова пошукового портрета серійного злочинця. - Стаття.

Пошуковий портрет злочинців складається здебільшого під час розслідування серійних насильницьких злочинів - згвалтувань, сексуальних вбивств, ритуальних вбивств. Криміналістична практика розробки і реалізації пошукових портретів серійних злочинців має багаторічну історію. Проте протягом багатьох років всі розшукові слідчі дії та виявлення й викривання злочинців базувались на практичному досвіді й «оперативному відчутті» тих, хто здійснював розслідування.

Залежно від змісту й характеру отриманої інформації пошуковий портрет невідомого злочинця може містити такі дані: загальна характеристика особистості і формуюча мотивація поведінки; звички, схильності, навички та інші індивідуальні ознаки особистості; вікова група; район, де ймовірно проживає злочинець; район місця роботи, служби, навчання; рівень освіти й професійна діяльність; особливості родини та історія особистого життя; сімейний стан і наявність дітей; служба в армії, заняття спортом, робота з людьми; наявність судимості (кримінальна обізнаність); наявність психічної патології; антропологічна і функціональна характеристика.

3 метою підвищення ефективності діяльності правоохоронних органів по розслідуванню серійних насильницьких злочинів пропонуємо такі рекомендації: 1) розробити принципово нову методику розслідування серійних насильницьких злочинів шляхом складання пошукових портретів злочинців; 2) створити інформаційну базу даних (інформаційно-пошукову систему) про серійних злочинців з урахуванням базових складників пошукового портрету злочинця (стать, вік, сімейний стан, освіта та інший); 3) запровадити нові експертні системи та системи підтримки прийняття рішень для роботи фахівців по складанню пошукових портретів злочинців (профілерів); 4) запровадити обов'язкову реєстрацію серійних злочинців, які мають певні відхилення психічного розвитку; 5) налагодити обмін інформацією про пошукові портрети злочинців зацікавленим відомствам, як в Україні, так і за її межами; 6) організувати відповідні наукові дослідження в галузі створення пошукових портретів злочинців.

Ключові слова: пошуковий портрет злочинця, серійні злочини, вбивства, фактор часу нападу.

\section{Summary}

Husar L. V. Construction of a search portrait of a serial criminal. - Article.

The searching portrait of criminals is folded, in most cases, at investigation of serial crimes of violence raping, sexual murders, ritual murders. The forensic practice of developing and implementing search portraits of serial criminals has a long history. However, for many years, all investigative actions and the detection and detection of criminals were based on the practical experience and "operational sense" of those who carried out the investigation.

Depending on maintenance and character of the got information the searching portrait of unknown criminal can contain such data: general description of personality and forming motivation of behavior; habits, inclinations, skills and other individual signs of personality; age related group; district, where a criminal lives probably; district of job, service, studies; level of education and professional activity; features of family and history of personal life; marital status presence of children; service of military forces, going in for sports, conversation with people; presence of previous convictions (criminal aware- 
ness); presence of psychical pathology; anthropological and functional description.

With the aim of increase of efficiency of activity of law enforcement authorities on investigations of serial crimes of violence, offer such recommendations: 1) to work out fundamentally new methodology of investigations of serial crimes of violence by the stowage of searching portraits of criminals; 2 ) to create an informative data base (information storage and retrieval system) about serial criminals taking into account the base constituents of searching taking into account the base constituents of searching to the portrait criminal (sex, age, marital sta- tus, education and other); 3) to enter new consulting models and systems of support of making decision for work of specialists on the stowage of searching portraits of criminals; 4) to enter obligatory registration of serial criminals that have certain rejections of psychical development; 5) to put right an exchange information about the searching portraits of criminals to the interested departments, as in Ukraine so after her limits; 6) to organize corresponding scientific researches in industry of creation of searching portraits.

Key words: seach portrait of a criminal, serial crimes, murders, attack time factor. 